\title{
IMPLEMENTASI POMPA AIR OTOMATIS TENAGA SURYA UNTUK RUMAH IBADAH
}

\author{
Muldi Yuhendri ${ }^{1}$, Aswardi $^{2}$, Hambali ${ }^{3}$ \\ 1 Universitas Negeri Padang \\ Korespondensi email: muldiy@ft.unp.ac.id \\ 2Universitas Negeri Padang \\ email: aswardimt@gmail.com \\ 3Universitas Negeri Padang \\ email: hambali.rsyd@gmail.com
}

\begin{abstract}
Clean water is one of the most vital needs for a mosque. Clean water is generally taken from wells using electric water pumps. The use of water pumps is often a problem in areas where the electricity network is often off, as happened in the Raya Mosque of Nagari Salareh Aia, Palembayan District, Agam Regency. To overcome this problem, a solar automatic water pump is designed which is equipped with a battery as a backup power supply and one phase inverter to convert the solar panel voltage to alternating voltage according to the voltage of the water pump motor. The water pump automation is designed using a floating switch installed in a water tank. This solar water pump is implemented using a 300 wp solar panel, a 90 Ah battery and a 1200 Watt inverter. This solar water pump is also equipped with a solar charger for charging and discharging batteries. Field test results show that the automatic solar water pump proposed in this service program has been working properly according to the plan.
\end{abstract}

Keywords: mosque; solar panel; charger; water pump.

\begin{abstract}
ABSTRAK
Air bersih adalah salah satu kebutuhan yang sangat vital untuk rumah ibadah. Air bersih ini umumnya diambil dari sumur menggunakan pompa air tenaga listrik. Penggunaan pompa air ini sering menjadi masalah pada daerah-daerah yang jaringan listriknya sering mati, seperti yang terjadi di Masjid Raya Nagari Salareh Aia, Kecamatan Palembayan, Kabupaten Agam. Untuk mengatasi masalah ini, maka dirancang pompa air otomatis tenaga surya yang dilengkapi dengan baterai sebagai penyedia energi listrik cadangan dan inverter satu fasa untuk mengkonversikan tegangan searah panel surya menjadi tegangan bolak balik sesuai dengan kebutuhan motor pompa air. Otomasi pompa air dirancang menggunakan sakelar apung yang dipasang dalam tangki air. Pompa air tenaga surya ini diimplementasikan dengan menggunakan panel surya 300 wp, baterai 90 Ah dan inverter 1200 Watt. Pompa air tenaga surya ini juga dilengkapi dengan solar charger untuk pengaturan pengisian dan pengosongan baterai. Hasil pengujian di lapangan menunjukan bahwa pompa air otomatis tenaga surya yang diusulkan dalam program pengabdian ini telah bekerja dengan baik sesuai dengan perencanaan.
\end{abstract}

Kata Kunci: masjid; panel surya; charger; pompa air. 


\section{PENDAHULUAN}

Masjid Raya Kampung Tangah adalah salah satu rumah ibadah yang ada di Nagari Salareh Aia, Kecamatan Palembayan, Kabupaten Agam. Berdasarkan observasi di lapangan, Masjid Raya ini merupakan Masjid yang paling aktif digunakan oleh masyarakat Nagari Salareh Aia. Selain sebagai tempat ibadah, Masjid ini juga dipakai sebagai tempat TPA dan TK. Melihat kondisi aktivitas Masjid ini yang begitu banyak, maka Masjid harus memiliki sarana dan prasarana yang memadai untuk menunjang kelancaran aktivitas tersebut. Salah satu prasarana yang sangat vital untuk rumah ibadah adalah tersedianya air bersih yang memadai untuk kebutuhan berwudhu, bersuci maupun untuk kebutuhan lainnya. Berdasarkan observasi yang dilakukan di lapangan, penyediaan air bersih di Masjid Raya ini disuplai dari sebuah sumur ukuran $2 \times 2$ meter dengan kedalaman 8 meter yang terdapat di samping Masjid. Air sumur ini dialirkan ke tempat berwudhu menggunakan pompa air yang disuplai oleh jaringan listrik. Pompa air ini sering tidak dapat dioperasikan karena jaringan listrik yang sering mati. Hal ini menyebabkan pengambilan air dari sumur sering dilakukan secara manual dengan ember oleh jamaah Masjid.

Untuk mengatasi masalah ini, maka dalam program pengabdian masyarakat ini diusulkan pompa air dengan menggunakan sumber energi listrik lain. Salah satu sumber energi listrik lain yang banyak digunakan untuk mengoperasikan pompa air adalah tenaga surya dengan menggunakan panel surya (Hartono \& Purwanto, 2015). Pompa air tenaga surya ini banyak dikembangkan karena memiliki kelebihan antara lain mudah diimplementasikan dan sumber energi utamanya berupa cahaya matahari dapat diperoleh secara gratis (Rezae \& Gholamian, 2013). Berdasarkan keuntungan yang dimiliki oleh pompa air tenaga surya ini, maka dalam program pengabdian ini diusulkan pompa air tenaga surya untuk penyediaan air bersih di Masjid Raya Nagari Salareh Aia.

Walaupun cahaya matahari sebagai sumber energi utama pada pompa air tenaga surya dapat diperoleh secara gratis, tapi ketersediaanya hanya pada siang hari, sehingga pompa air tidak dapat dioperasikan pada malam hari. Untuk mengatasi masalah ini, maka pompa air tenaga surya harus dilengkapi dengan peralatan penyimpan energi yang dapat menyimpan energi pada siang hari dan menyuplai energi ketika cahaya matahari tidak ada pada malam hari. Penyimpanan energi pada pompa air tenaga surya secara umum dapat dikategorikan atas dua jenis, yaitu penyimpan energi dalam bentuk energi listrik dan penyimpanan energi dalam bentuk energi air (Shaikh \& Jain, 2016). Penyimpanan energi listrik pada pompa air tenaga surya umumnya menggunakan baterai atau super kapasitor, sedangkan penyimpanan energy air umumnya menggunakan tangki air atau bak air (Al-Badi et al., 2018). Dalam program pengabdian ini, sistem penyimpanan energi pada pompa air tenaga surya dirancang dengan mengkombinasikan baterai sebagai penyimpan energy listrik dan tangki air sebagai penyimpan energi air. 
Kombinasi ini diharapkan dapat menjaga kontiniutas penyediaan air bersih di rumah ibadah. Penggunaan baterai pada panel surya membutuh sistem kendali yang dapat mengatur pengisian dan pengosongan baterai (lqtimal et al., 2018). Sistem kendali harus dapat mengatur pengisian baterai ketika daya yang dihasilkan panel surya melebih daya yang dibutuhkan pompa air pada siang hari. Sebaliknya, sistem kendali harus mampu mengatur penyaluran daya dari baterai ke pompa ketika daya yang dihasilkan panel surya di bawah daya yang dibutuhkan motor pompa air. Dalam program pengabdian ini, digunakan solar charger 40 Ampere untuk sistem kendali baterai ini.

Pompa air tenaga surya umumnya menggunakan pompa sentrifugal, yaitu pompa air yang bekerja berdasarkan daya sentrifugal yang dihasilkan oleh impeller (kipas) yang diputar oleh motor listrik (Keerthana et al., 2015). Ada beberapa jenis motor listrik yang digunakan untuk pompa air, seperti motor induksi, Brushless DC motor, switched reluctance motor, permanent magnet synchronous motor dan sebagainya (Singh et al., 2015; Apribowo et al., 2017; Kumar \& Singh, 2017; Riyadi, 2017; Antonello et al., 2017). Dalam pengabdian ini, pompa air yang dirancang digerakan dengan motor induksi satu fasa. Karena motor induksi yang digunakan dalam bentuk ac, maka tegangan dc yang dihasilkan panel surya perlu dikonversikan ke bentuk ac menggunakan inverter. Dalam kegiatan ini, digunakan inverter satu fasa pure sinusoidal dengan rating daya 1200 Watt.

Untuk memudahkan masyarakat dalam mengoperasikan pompa air tenaga surya, maka pompa air tenaga surya yang diusulkan dalam program pengabdian ini dirancang secara otomatis dengan menggunakan sakelar apung yang dipasang di dalam tangki air. Sakelar ini akan memutuskan rangkaian listrik ke motor pompa ketika tangki air dalam kondisi penuh, sebaliknya sakelar ini akan menghubungkan rangkaian panel surya ke motor ketika tangki belum penuh. Dengan konsep ini, pompa air tenaga surya dapat bekerja secara otomatis, sehingga memudahkan masyarakat dalam pengoperasiannya.

\section{METODE PELAKSANAAN}

Program pengabdian masyarakat ini dilaksanakan dalam bentuk eksperimen dengan merancang dan membuat pompa air otomatis tenaga surya untuk penyediaan air bersih di Masjid Raya Nagari Salareh Aia, Kecamatan Palembayan, Kabupaten Agam. Program pengabdian masyarakat ini dilakukan dalam beberapa tahapan, yang mencakup tahapan observasi, perancangan, pemasangan dan pengujian.

\section{Observasi Lapangan}

Observasi dilakukan untuk melihat dan menganalis masalah yang dihadapi oleh masyarakat. Sebelum melakukan observasi, terlebih dahulu ditetapkan topik pengabdian yang akan dilakukan. Berdasarkan sumber daya yang dimiliki oleh tim, maka topik pengabdian difokuskan pada penerapan pompa air tenaga surya pada daerah yang belum dialiri oleh 
jaringan listrik atau pada daerah yang kehandalan jaringan listriknya rendah. Berdasarkan topik ini, dipilihlah Nagari Salareh Aia sebagai lokasi pengabdian, karena daerah ini memiliki kehandalan jaringan listrik yang rendah. Agar penerapan teknologi yang dilakukan dapat dirasakan oleh masyarakat umum, maka lokasi pengabdian difokuskan pada fasilitas umum. Dengan alasan ini, maka dipilihlah Masjid Raya Nagari Salareh Aia sebagai tempat pemasangan pompa air tenaga surya yang diusulkan dalam program ini.

Observasi dilakukan dengan melihat langsung ke lokasi dan wawancara dengan masyarakat sekitar. Gambar 1 menunjukan lokasi pengabdian dan kondisi sumur yang digunakan oleh masrayakat untuk kegiatan di masjid.
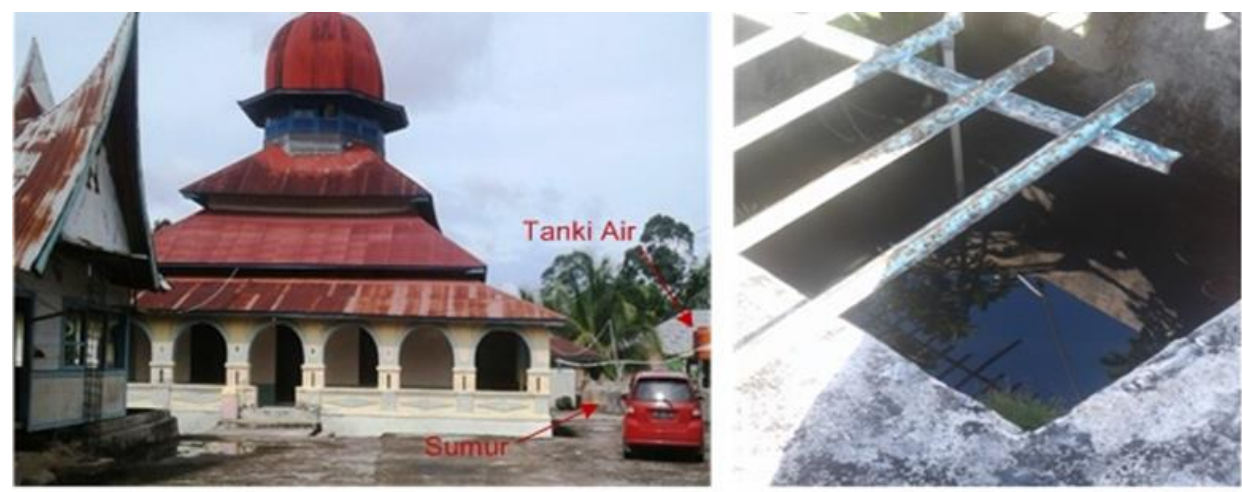

Gambar 1. Lokasi pengabdian

\section{Perancangan Pompa Air Otomatis Tenaga Surya}

Pompa air otomatis tenaga surya yang diusulkan dalam pengabdian ini dirancang untuk dapat menjamin ketersediaan air bersih di Masjid Raya Salareh Aia. Untuk mencapai tujuan ini, maka dirancang sistem pompa air otomatis tenaga surya dengan skema seperti yang ditunjukan oleh Gambar 2. Pompa air ini dirancang menggunakan pompa sentrifugal berkapasitas 18 liter/menit yang digerakan dengan motor induksi satu fasa 125 watt. Kapasitas pompa ini sudah sukup memadai dalam menyediakan air bersih pada Masjid tersebut. Pompa ini dihubungkan secara langsung dengan tangki air berkapasitas 1000 liter. Tangki ini akan menyuplai kran kran air pada tempat wudhu dan toilet yang ada di Masjid tersebut. Untuk menyuplai pompa, digunakan panel surya 300 WP tipe Monocrystalline. Daya panel surya ini dianggap sudah cukup memadai menyuplai pompa dan baterai secara bersamaan, sehingga pengisian baterai tetap dapat dilakukan ketika pompa sedang hidup. Untuk penyimpan daya listrik digunakan dua buah baterai 45 Ah 12 Volt yang dihubungkan secara seri, sehingga rating tegangannya mendekati sama dengan rating tegangan panel surya, yakni 24 Volt. 


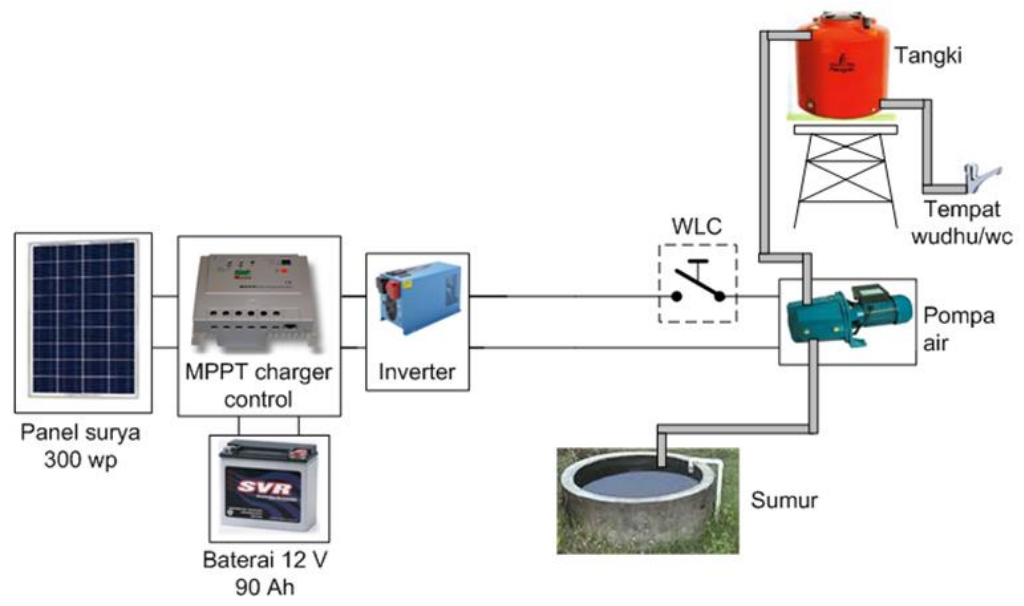

Gambar 2. Skema pompa air otomatis tenaga surya

Untuk pengendalian pengisian baterai digunakan solar charger 40 Ampere, sedangkan untuk mendapatkan tegangan ac dari panel surya digunakan inverter 1200 Watt. Sistem ini juga dilengkapi dengan sakelar apung yang dipasang di dalam tangki air untuk otomasi pengisian air pada tangki.

\section{Pemasangan Pompa Air Otomatis Tenaga Surya}

Pemasangan pompa air otomatis tenaga surya di lokasi pengabdian dilakukan oleh tim yang terdiri dari dosen dan teknisi. Dalam menyelesaikan pekerjaan di lapangan, tim pengabdian juga dibantu oleh masyarakat sekitar Masjid.

Pekerjaan pemasangan pompa air tenaga surya dimulai dengan pemasangan panel surya dan kotak panel kontrol yang berisi inverter dan solar charger dan baterai. Untuk meningkatkan dan suhu pada permukaan panel surya, maka panel surya dipasang di atas atap Masjid. Box panel kontrol dipasang di dalam Masjid, dimana kotaknya ditempatkan di dinding, sedangkan baterainya ditempatkan di lantai. Gambar 3 menunjukan pemasangan panel surya dan panel kontrol.
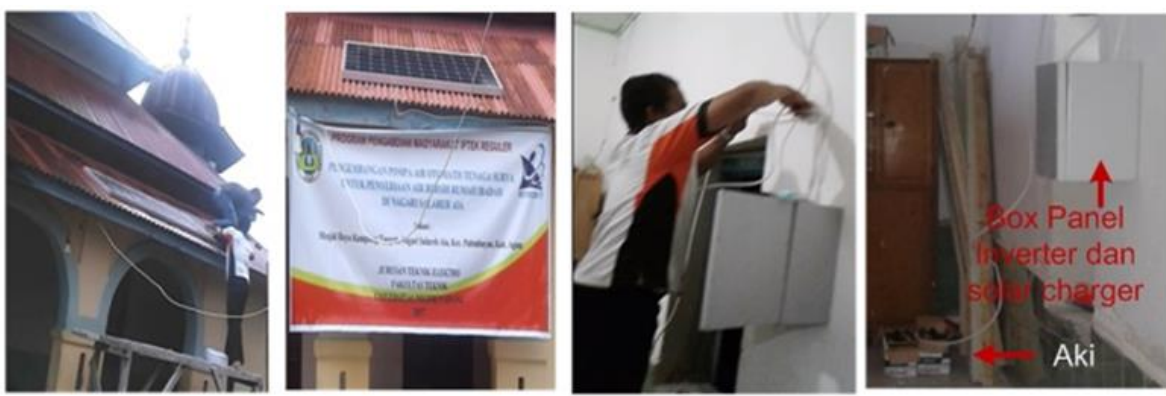

Gambar 3. Pemasangan panel surya dan kotak panel kontrol 
Setelah pemasangan panel surya dan kotak panel kontrol selesai, selanjutnya dilakukan pemasangan pompa air, sakelar apung, pipa dan instalasi listrik. Motor pompa air dipasang di pinggir sumur, seperti yang ditunjukan oleh Gambar 4. Sakelar apung dipasang di dalam tangki air yang sudah ada sebelumnya. Gambar 4 menunjukan hasil pemasangan sakelar apung pada tangki air. Setelah pemasangan semua komponen pompa air tenaga surya selesai, selanjutnya pada hari kedua dilakukan pengujian, yang mencakup pengujian panel surya dan pengujian pompa air.
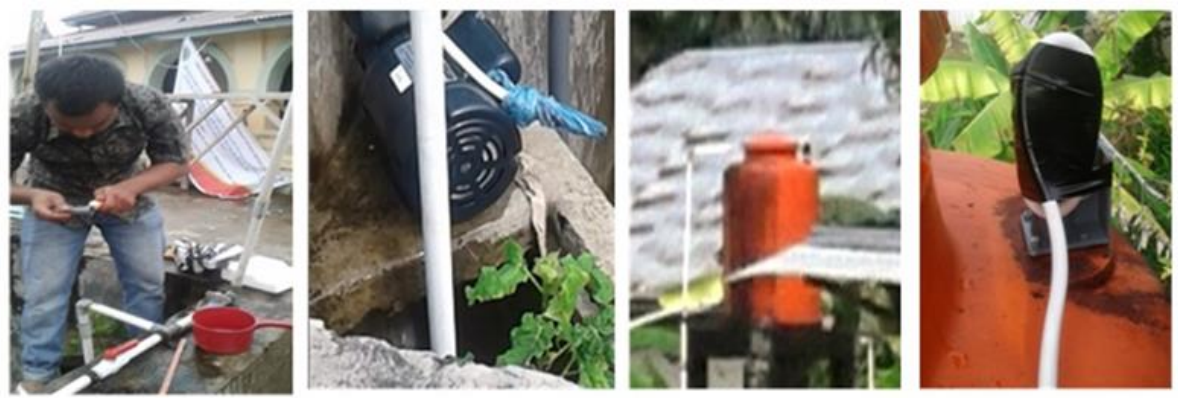

Gambar 4. Pemasangan pompa dan sakelar apung

\section{HASIL DAN PEMBAHASAN}

Hasil implementasi pompa air otomatis tenaga surya divalidasi melalui pengujian, yang mencakup pengujian kelistrikan panel surya dan pengujian kinerja pompa air.

\section{Hasil Pengujian Panel Surya}

Pengujian panel surya dilakukan pada hari kedua di lapangan. Pengujian ini ditujukan untuk melihat karakteristik tegangan yang dihasilkan panel surya, baterai dan inverter. Pengujian dilakukan pada terminal terminal panel surya, baterai dan inverter yang ada pada kotak panel kontrol. Pengujian dilakukan dengan menggunakan power analyzer Fluke 41B.

Pengukuran pertama dilakukan untuk melihat performansi tegangan pada sisi dc kotak panel kontrol. Parameter tegangan pada sisi dc panel control ini mencakup tegangan output panel surya yang diinputkan pada solar charger, tegangan output solar charger yang diinputkan pada inverter dan tegangan baterai. Pengukuran ini dilakukan pada pukul 10.00 WIB pagi hari dengan radiasi matahari pada permukaan panel 900 lumen dan suhu $36^{\circ} \mathrm{C}$. Gambar 5 menunjukan grafik tegangan pada sisi dc kotak panel, yang mencakup tegangan output panel surya, tegangan output charger dan baterai. 


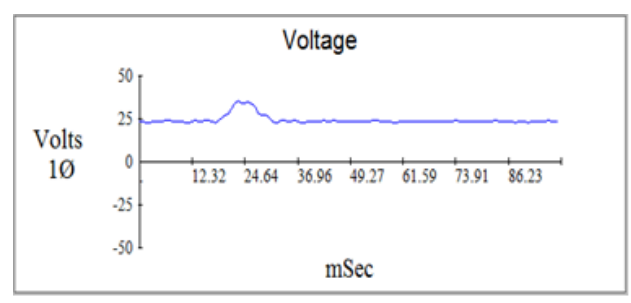

(a)

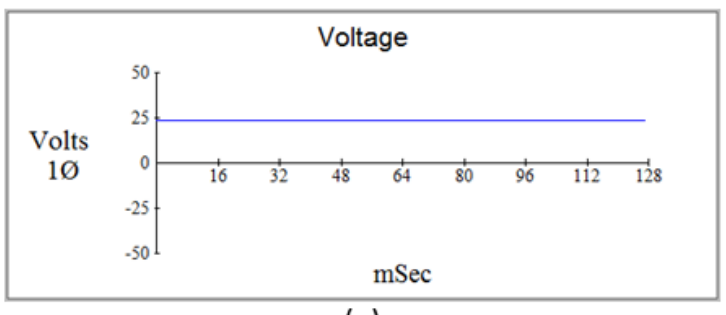

(c)

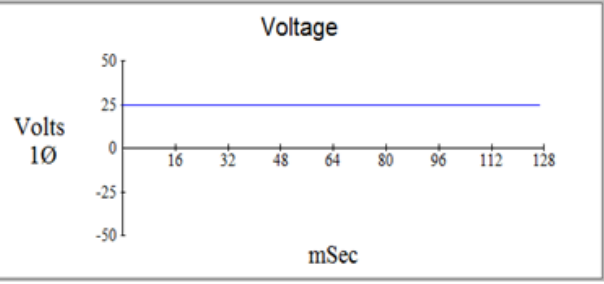

(b)

Gambar 5. Performansi tegangan dc. (a) output panel surya (b) output solar charger dan (c) tegangan baterai

Gambar 5 menunjukan bahwa saat pengujian diperoleh tegangan output panel surya sebesar 31 Volt. Nilai ini masih di bawah nilai tegangan maksimum panel surya, yakni 37 Volt. Hal ini menunjukan bahwa tegangan yang dihasilkan panel surya belum maksimum, sehingga daya outputnya juga belum maksimum. Hal ini disebabkan oleh kondisi radiasi dan suhu pada panel surya belum maksimum, karena masih pagi hari. Dalam pengukuran ini diperoleh nilai tegangan output solar charger sebesar 25.05 Volt dan tegangan baterai sebesar 23.5 Volt. Hasil pengujian ini menunjukan bahwa baterai dalam kondisi pengisian. Hasil ini juga menunjukan bahwa tegangan output yang dihasilkan solar charger sudah sesesuai dengan standar tegangan input inverter, yaitu sekitar 24 Volt. Berdasarkan hasil ini dapat disimpulkan bahwa panel surya, baterai dan solar charger telah berfungsi dengan baik.

Selanjutnya dilakukan pengukuran tegangan output inverter. Dalam pengujian ini, output inverter dihubungkan dengan motor pompa air, sedangkan inputnya dihubungkan dengan output solar charger. Gambar 6 menunjukan gelombang tegangan dan arus output inverter pada alat ukur power analyzer Fluke 41B. Hasil pengukuran menunjukan bahwa tegangan dan arus output inverter sudah dalam bentuk sinusoidal dengan Total Harmonic Distortion (THD) tegangan sebesar $0.51 \%$ dan THD arus sebesar $21.81 \%$. Sehingga dapat disimpulkan bahwa inverter telah bekerja dengan baik mengkonversikan tegangan dc panel surya menjadi tegangan ac sesuai dengan kebutuhan motor pompa air. 


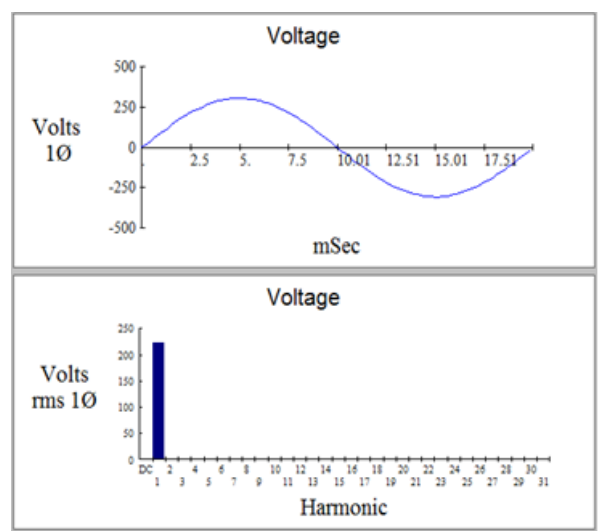

(a)

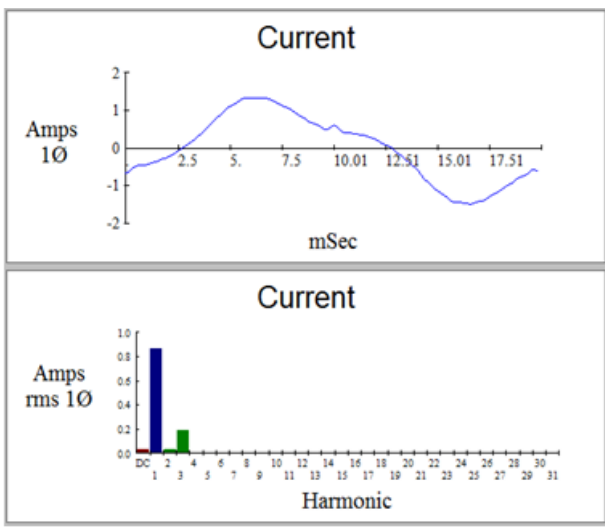

(b)

Gambar 6. Performansi inverter. (a) Tegangan dan (b) arus

Ringkasan hasil pengukuran dengan Power analyzer Fluke 41B ditunjukan oleh Gambar 7.

\begin{tabular}{|c|c|c|c|c|}
\hline \multicolumn{3}{|c|}{ Summary Information } & \multirow{2}{*}{\begin{tabular}{|c|} 
Voltage \\
222.0
\end{tabular}} & \multirow{2}{*}{$\begin{array}{c}\text { Current } \\
\mathbf{0 . 8 9}\end{array}$} \\
\hline Frequency & 4997 & RMS & & \\
\hline Power & 49.38 & Peak & 314.3 & $\begin{array}{l}0.85 \\
1.45\end{array}$ \\
\hline Watts & 153.00 & DC Offset & -0.2 & -0.03 \\
\hline VA & 197.00 & Crest & 1.42 & 1.63 \\
\hline Vars & 116.00 & THD Rms & 0.51 & 21.81 \\
\hline Peak W & 443.00 & THD Fund & 0.51 & 22.35 \\
\hline Phase & $37^{*}$ lag & HRMS & 1.1 & 0.19 \\
\hline Total PF & 0.78 & KFactor & & 1.65 \\
\hline DPF & 0.80 & & & \\
\hline
\end{tabular}

Gambar 7. Ringkasan hasil pengukuran dengan Power analyzer Fluke 41B

Gambar 7 menunjukan bahwa inverter menyalurkan daya ke pompa air sebesar 153 Watt dengan faktor daya 0.78 dan frekuensi 49.97 $\mathrm{Hz}$. Jumlah daya ini masih jauh di bawah nilai maksimal dari daya panel surya, yaitu 300 Watt-Peak (WP). Hasil ini menunjukan bahwa panel surya masih memungkinkan untuk menyuplai motor dan baterai secara bersamaan ketika daya yang dihasilkan melebihi daya motor pompa air.

Semua hasil pengukuran yang dilakukan menunjukan bahwa rancangan panel surya untuk pompa air otomatis telah bekerja dengan baik, dimana panel surya sudah dapat menyuplai motor pompa air sesuai dengan tegangan dan daya yang dibutuhkan motor pompa air.

\section{Hasil Pengujian Pompa Air}

Setelah hasil pengukuran parameter panel surya dinyatakan valid, selanjutnya dilakukan pengujian pompa air tenaga surya, yang mencakup kemampuan pompa mengalirkan air ke tangki dan sistem otomasi 
pengisian air pada tangki. Gambar 8 menunjukan hasil pengujian pompa air tenaga surya yang dilakukan di lokasi pengabdian. Gambar pertama pada Gambar 8 menunjukan kondisi tangki yang sedang kosong dengan sakelar apung yang masih menggantung. Pada kondisi ini sakelar akan menghubungkan rangkaian panel surya dengan motor pompa, sehingga pompa beroperasi mengalirkan air dari sumur ke tangki air, seperti yang ditunjukan oleh Gambar kedua. Gambar ketiga menunjukan aliran air pada kran yang terdapat di tempat wudhu yang akan menyebabkan berkurangnya air dalam tangki. Gambar keempat menunjukan kondisi air dalam tangki sudah penuh, sehingga sakelar apung mengambang dan akan memutukan aliran listrik dari panel surya ke motor pompa, sehingga motor pompa berhenti bekerja. Dengan konsep ini, maka air dalam tangki tidak akan pernah melimpah keluar. Semua hasil pengujian ini menunjukan bahwa pompa air otomatis tenaga surya yang diusulkan dalam program pengabdian ini telah bekerja dengan baik.
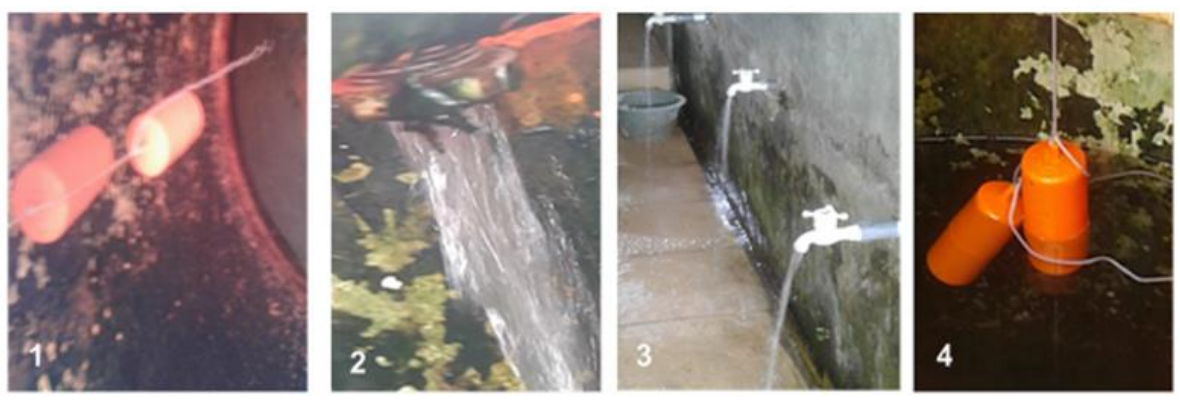

Gambar 8. Hasil pengujian pompa air

Selanjutnya dilakukan pengujian pompa air pada saat cahaya matahari tidak ada untuk melihat kemampuan baterai dalam meyuplai pompa. Pengujian dilakukan pada saat magrib, isya dan subuh. Pada sore hari, data kapasitas baterai menunjukan 95\%. Ketika pompa air dioperasikan pada waktu magrib selama 1 jam, kapasitas baterai turun menjadi $75 \%$. Kemudian pompa air kembali dioperasikan pada waktu isya selama 30 menit, maka kapasitas baterai turun menjadi $60 \%$. Selanjutnya pompa air kembali dioperasikan pada waktu subuh selama 30 menit, kapasiitas baterai turun menjadi 55\%. Gambar 9 menunjukan data kapasitas baterai yang ditampilkan pada layar solar charger ketika pompa air selesai dioperasikan pada waktu subuh. Hasil ini menunjukan bahwa baterai telah mampu menyuplai pompa air selama 2 jam ketika cahaya matahari tidak ada. 


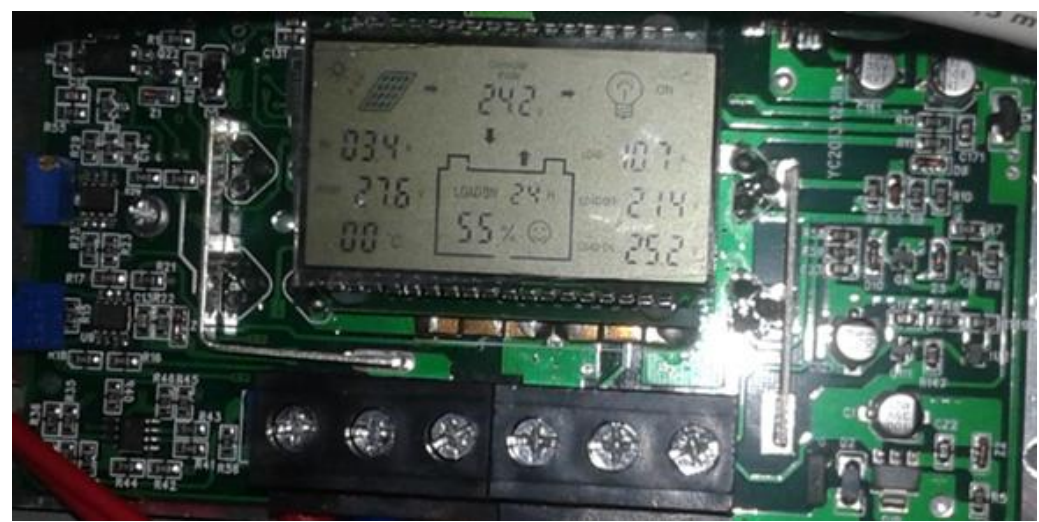

Gambar 9. Tampilan kapasitas baterai pada solar charger

Setelah semua hasil pengujian pompa air otomatis tenaga surya dinyatakan valid, maka selanjutnya dilakukan serah terima produk dengan Wali Nagari Salareh Aia yang disaksikan oleh para pengurus dan Jamaah Masjid. Gambar 10 menunjukan proses serah terima produk pompa air otomatis tenaga surya dengan Wali Nagari Salareh Aia.

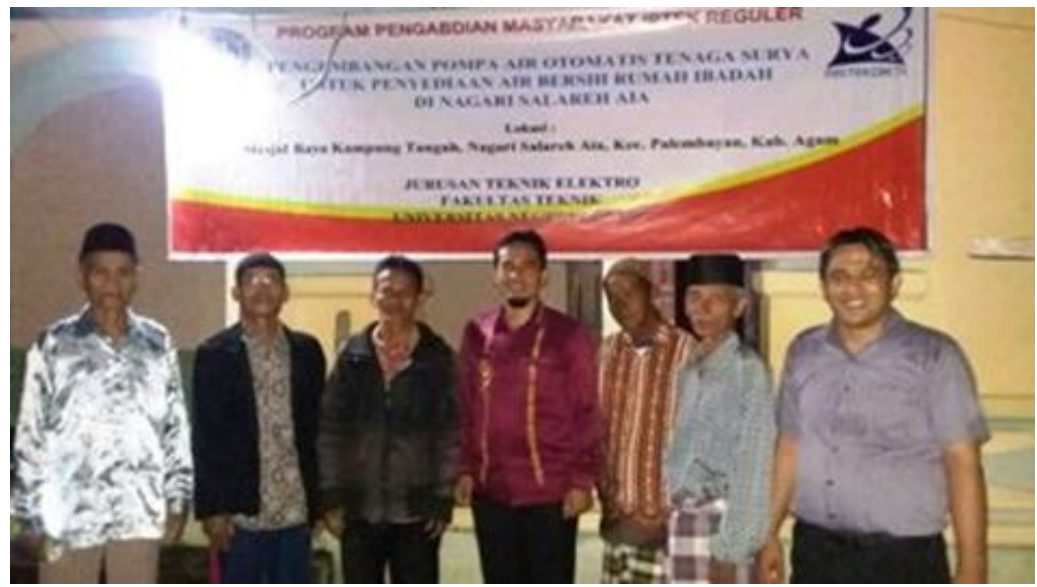

Gambar 10. Serah terima produk pompa air tenaga surya dengan Wali Nagari

\section{KESIMPULAN}

Pemanfaatan tenaga surya untuk pompa air otomatis dirancang untuk memenuhi kebutuhan air bersih di Masjid Raya Nagari Salareh Aia, Kecamatan Palembayan Kab. Agam. Alat ini menggunakan panel surya 300 wp untuk menyuplai pompa air yang digerakan oleh motor induksi 1 fasa 125 watt 220 Volt. Pompa air otomatis tenaga surya ini dilengkapi dengan solar charger, inverter dan baterai untuk menyimpan energi listrik serta tangki air untuk menyimpan air. Sistem otomasi pompa air dirancang dengan menggunakan sakelar apung yang dipasang di dalam tangki air. Pemasangan dan pengujian pompa air otomatis tenaga surya di lokasi pengabdian 
dilakukan selama dua hari. Berdasarkan hasil pengujian di lokasi pengabdian dapat disimpulkan bahwa pompa air otomatis tenaga surya yang dirancang telah bekerja dengan baik sesuai dengan perencanaan. Pompa air tenaga surya telah mampu meningkatkan ketersediaan air bersih di masjid walaupun jaringan listrik sering mati. Untuk kedepannya, diharapkan kapasitas panel surya ditingkatkan, sehingga bisa juga dimanfaatkan untuk penerangan dan kebutuhan lainnya ketika jaringan listrik mati.

\section{UCAPAN TERIMA KASIH}

Tim pengabdian mengucapkan terimakasih kepada LP2M Universitas Negeri Padang yang telah membiayai program pengabdian ini.

\section{DAFTAR RUJUKAN}

Al-Badi, A., Yousef, H., Mahmoudi, T. Al, Al-Shammaki, M., Al-Abri, A., \& AlHinai, A. (2018). Sizing and modelling of photovoltaic water pumping system. International Journal of Sustainable Energy, 37(5), 415-427. https://doi.org/10.1080/14786451.2016.1276906

Antonello, R., Carraro, M., Costabeber, A., Tinazzi, F., \& Zigliotto, M. (2017). Energy-Efficient Autonomous Solar Water-Pumping System for Permanent-Magnet Synchronous Motors. IEEE Transaction on Industrial Eletcronic, 64(1), 43-51. https://doi.org/10.1109/TIE.2016.2595480

Apribowo, C. H. B., S., T. E., \& Anwar, M. (2017). Prototype Sistem Pompa Air Tenaga Surya Untuk Meningkatkan Produktivitas Hasil Pertanian. Jurnal Abdimas, 21(2), 97-102. https://journal.unnes.ac.id/nju/index.php/abdimas/article/view/12336

Hartono, B., \& Purwanto. (2015). Perancangan Pompa Air Tenaga Surya Guna Memindahkan Air Bersih ke Tangki Penampung. SINTEK, 9(1), 28-33. https://jurnal.umj.ac.id/index.php/sintek/article/view/296

Iqtimal, Z., Sara, I. D., \& Syahrizal. (2018). Aplikasi Sistem Tenaga Surya Sebagai Sumber Tenaga Listrik Pompa Air. KITEKTRO: Jurnal Online Teknik Elektro, 3(1), $1-8$. http://www.jurnal.unsyiah.ac.id/kitektro/article/view/9991

Keerthana, C., Siri, R. S., Arthi, A., \& Rani, S. S. (2015). Hybrid Water Pumping Control System for Irrigation using Arduino. International Journal of Engineering Research and Technology (IJERT), 4(3), 859863. https://doi.org/10.17577/ijertv4is030914

Kumar, R., \& Singh, B. (2017). Solar PV powered BLDC motor drive for water pumping using Cuk converter. IET Electric Power Applications, 11(2), 222-232. https://doi.org/10.1049/iet-epa.2016.0328

Rezae, A., \& Gholamian, S. A. (2013). Technical and Financial Analysis of Photovoltaic Water Pumping System for GORGAN, IRAN. International Journal on Cybernetics \& Informatics (IJCI), 2(2), 21-31. https://doi.org/10.5121/ijci.2013.2203 
Riyadi, S. (2017). Design of photovoltaic BLDC motor-water pump system with single converter. 3rd International Conference on Information Technology, Computer, and Electrical Engineering (ICITACEE). https://doi.org/10.1109/ICITACEE.2016.7892439

Shaikh, S. R., \& Jain, A. M. (2016). A literature survey of photovoltaic water pumping system. International Conference on Control, Instrumentation, Communication and Computational Technologies (ICCICCT). https://doi.org/10.1109/ICCICCT.2015.7475333

Singh, B., Mishra, A. K., \& Kumar, R. (2015). Solar powered water pumping system employing switched reluctance motor drive. 6th IEEE Power India International Conference https://doi.org/10.1109/POWERI.2014.7117786

(PIICON). 